\title{
Effect of Dietary Energy and Stocking Density on the Performance and Sensible Heat Loss of Broilers Reared under Tropical Winter Conditions
}

\section{-Author(s)}

Nogueira WCL

Velásquez PAT

Furlan RL

M Macari

Department of Animal Morphology and Physiology.Faculdade de CiênciasAgrárias e Veterinárias - UNESP.Jaboticabal campus, São Paulo, Brazil.

\section{Mail Adress}

Corresponding author e-mail address macari@fcav.unesp.br

\section{-Keywords}

Housing environment, production capacity, sensible heat, broiler, radiation.

\section{ABSTRACT}

The objective of the present study was to evaluate the effects of different dietary energy levels and stocking densities on the thermoregulating parameters, live performance, and carcass traits of broilers reared under tropical winter conditions at different times of the day. In total, 1,312 one-d-old male broilers were used. Birds were allotted to three different stocking densities (10, 14 or 18 birds/ $\mathrm{m}^{2}$ ) and two dietary energy levels (2900 or $3200 \mathrm{kcal} \mathrm{ME} / \mathrm{kg}$ ). The following parameters were evaluated:radiant heat load $(\mathrm{RHL})$, rectal temperature $(\mathrm{RT})$, feed intake $(\mathrm{Fl})$, weight gain (WG), feed conversion ratio $(F C R)$, livability $(L)$, production of live weight per area (WA), and carcass yield. Stocking density did not affect sensible heat loss (SRL) or rectal temperature (RT); however, as expected, sensible heat loss (SRL) and RT were influenced by time of the day, with higher values in the morning and in the afternoon, respectively. There was no effect of treatment $(p>0.05)$ on carcass or parts yield. Feed intake was reduced in $3 \%$, whereas weight gain and feed conversion ratio improved in 8 and $10 \%$, respectively, as dietary energy level increased. On the other hand, stocking density did not influence live performance or carcass traits. Based on the present results, it is concluded that sensible heat loss depends on dietary energy levels and particularly on time of the day. Therefore, environmental house management is suggested during tropical winters in order to reduce differences between broiler skin and environmental temperatures in the morning and in the afternoon.

\section{INTRODUCTION}

Advances in genetics, nutrition, management, housing environment, etc., have been essential to promote better broiler performance. However, increasing production capacity in terms of live weight per area is still a challenge.

Several studies have shown that increasing stocking densities have negative effects on broiler growth, welfare, meat water retention capacity, feed intake and feed conversion ratio (Puron et al., 1995; Feddes et al., 2002; Dozier et al., 2005; 2006; Estevez, 2007). However, when housing environment is improved using ventilation and reducing the incidence of solar radiation, for instance, productivity $\left(\mathrm{kg}\right.$ meat $\left./ \mathrm{m}^{2}\right)$ considerably increases (Zanolla et al., 1999; Moreira et al., 2004).

Another relevant aspect in broiler production is the manipulation of dietary energy levels. Goldfus et al. (1997), studying dietary energy levels $(2,800 ; 3,000$ or $3,200 \mathrm{kcal} \mathrm{ME} / \mathrm{kg}$ ) and two stocking densities (10 or 22 birds $/ \mathrm{m}^{2}$ ) observed reduced feed intake, better feed conversion ratio, and higher abdominal fat content in the broilers fed the highest energy level. In another study, Oliveira Neto et al. (2000) showed that feed conversion ratio improved as dietary energy level increased. However, 
it was found that increasing dietary energy levels in different feeding programs did not result in significant carcass quality differences (Duarte et al., 2007).

The environment directly influences poultry survival and performance. Adequate housing facilities should provide adequate temperature, radiation, relative humidity, and air velocity inside the poultry houses in order to allow birds to maintain thermal balance at the lowest metabolic cost, thereby increasing their productivity. There are few studies relating thermoregulating mechanisms to productivity in broilers, such as on heat production, sensible or latent heat loss, surface and body temperature of broilers reared at different stocking densities, particularly under field conditions.

It is important to consider the relations between environmental temperature, stocking density and dietary energy level in order to maximize production. The objective of the present study was to evaluate the effects of different dietary energy levels and stocking densities on the thermoregulation, live performance, and carcass parameters of broilers reared under tropical winter conditions at different times of the day.

\section{MATERIALS AND METHODS}

The experiment was carried out in a facility located at 21015'22" S, 48018'58" W and $595 \mathrm{~m}$ altitude. According to Koppen's classification, the climate is Awa, described as dry tropical during winter, with a defined dry season (April to September), and rainy during the summer months. The environmental parameters air temperature and sun radiation were measured during the entire experimental period and are shown in Figures 1 and 2, respectively. Air relative humidity during the experimental period ranged between 70 and $90 \%$. This characterizes the so-called "Indian summer" during tropical winters, i.e., hot day and cold nights.

A total of 1,312 one-d-old male Ross broilers were distributed into $24(2.8 \times 1.4 \times 3.5 \mathrm{~m})$ pens in a clay-roof broilers house with East-West orientation. Birds were submitted to the conventional management used in commercial farms, and received feed and water ad libitum. The floor was covered with $10-\mathrm{cm}$ high woodshavings litter.

Feeds were based on corn and soybean meal, containing $22 \%$ crude protein (CP) in the starter (121 days) and grower (22-42 days) phases and supplied the nutritional requirements of each phase, according to Rostagno et al. (2005). A completely randomized experimental design in a $3 \times 2$ factorial arrangement, consisting of three stocking densities $(10,14$ or 18 birds $/ \mathrm{m}^{2}$ ) and two dietary energy levels (2,900 or 3,200 kcal ME/kg), was applied.

Bird surface temperature was measured using an infrared thermometer (IT-330-Horiba, Japan) in five body areas: back, base of the comb, tip of the right wing, left leg, and head. Rectal temperature was measured with the aid of a fine-tip probe (model 402 LN-K73517, Yellow Spring Instruments, YSI, USA) connected to a six-channel telethermometer (model

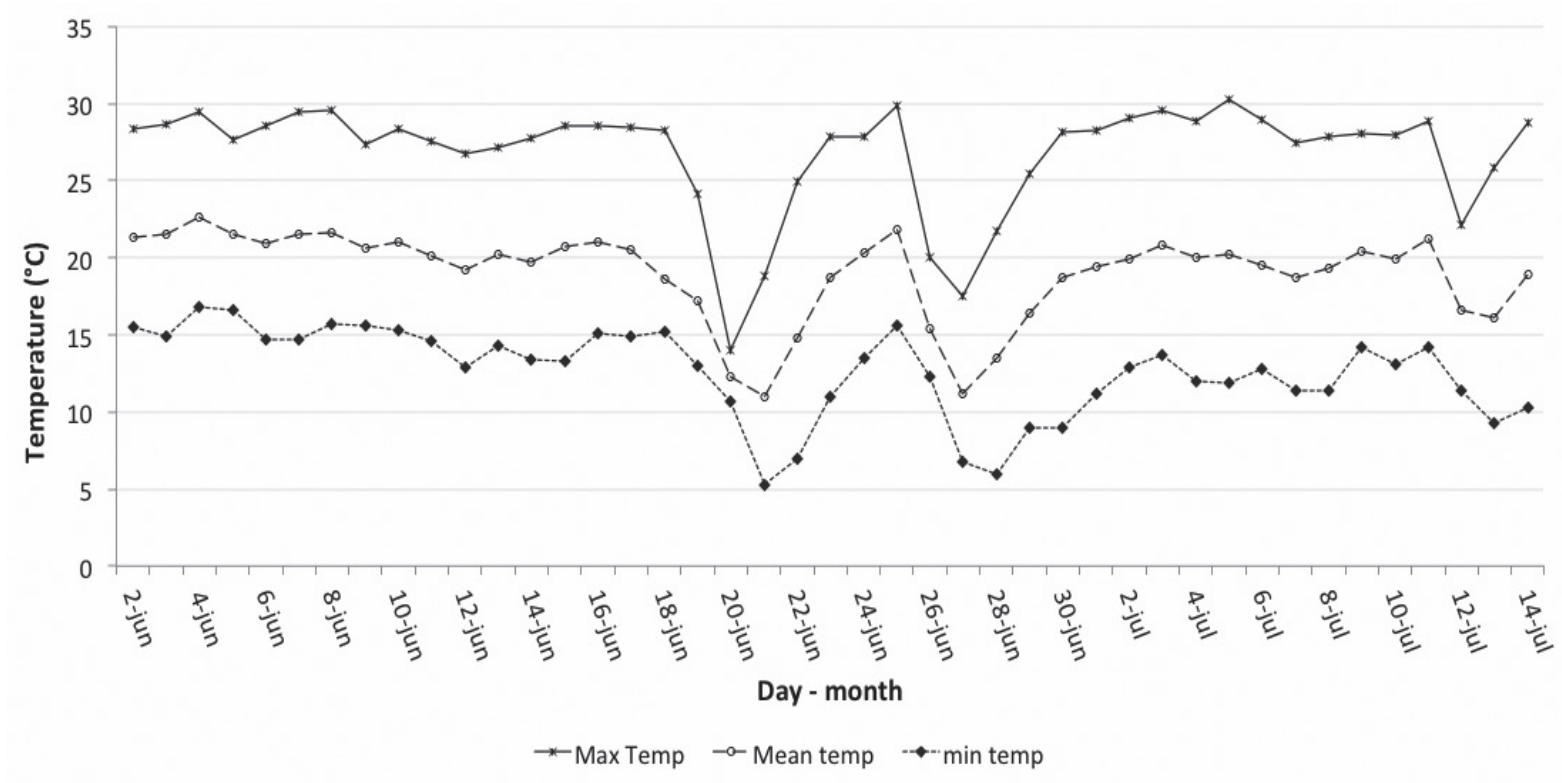




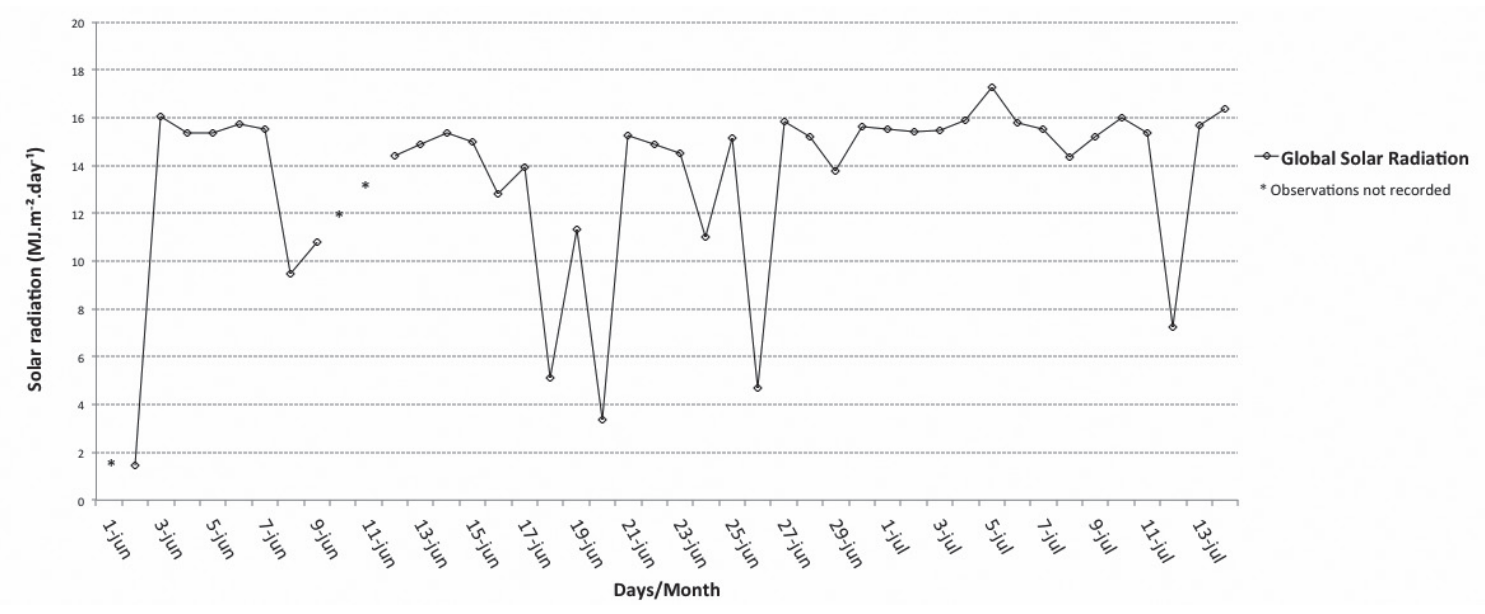

46 TUC, YSI, USA), which was inserted $4-7 \mathrm{~cm}$ inside the rectum. Data were collected from day 10, daily, in the morning (before sunrise, 06:30h) and when the sun passed by the meridian (zenith, approximately 12:30h).

In order to calculate sensible heat loss (SRL, in watts), the following equation was used:

$$
\mathrm{SRL}=\mathrm{ECA}\left(\mathrm{Ts}^{4}-\mathrm{Tg}^{4}\right) \text {, }
$$

where:

$E$ - surface emissivity (feathers $=0.94$ ),

C - Stefan-Bolzman's constant $\left(5.67 \times 10^{-8} \mathrm{~W} / \mathrm{m}^{2}\right)$,

Ts - average broiler surface temperature,

$\mathrm{Tg}$ - average environmental temperature, and

$\mathrm{A}=$ broiler surface area in $\mathrm{m}^{2}$, where:

$A=8.19 W^{0.67}$, where $W=$ body weight $(g)$.

The following performance parameters were evaluated:weight gain, feed intake, feed conversion ratio, livability, and meat production/area. At the end of the experiment, two birds per replicate were sacrificed and their carcasses evaluated for breast, drumstick+thighs (leg), wing, and abdominal fat yields.

Data were submitted to analysis of variance (ANOVA) using the General Linear Models procedure of SAS software program (SAS, 2000), and means were compared by the test of Tukey $(p \leq 0.05)$.

\section{RESULTS AND DISCUSSION}

Table 1 presents performance results as a function of stocking density and dietary energy level. Weight gain, feed intake, and feed conversion ratio were not influenced $(P>0.05)$ by stocking density. However, it must be mentioned that, as stocking density increased, feed intake of broilers housed at 14 and 18 birds/ $\mathrm{m}^{2}$ was, in average, 30 and $40 \mathrm{~g}$ lower, respectively, compared with those housed at a density of 10 birds/ $\mathrm{m}^{2}$. This feed intake difference may be explained by the restricted access to the feeders, as suggested by Sorensen et al. (2000) or by the restricted movement of broilers housed at higher densities (Estevez et al., 2007; Simsek et al., 2009). Consistent results were described by Moreira et al. (2004), who observed that stocking density did not influence feed conversion ratio in their experiment. The authors worked with stocking densities of 10,13 , and $16 \mathrm{birds} / \mathrm{m}^{2}$ and detected weight gain differences among birds. On the other hand, livability was significantly influenced ( $p \leq 0.05$ ) by stocking density, and presented 5.5 and $10.1 \%$ reduction in broilers housed at 14 and 18 birds $/ \mathrm{m}^{2}$ compared with those housed at 10 birds $/ \mathrm{m}^{2}$. As expected, meat production per area increased ( $p \leq$ $0.05)$ with stocking density.

Table 1 - Feed intake (FI, g), weight gain (WG, g), feed conversion ratio $(F C R)$, livability $(L, \%)$, and production of live weight per area (WA, $\mathrm{kg} \mathrm{LW} / \mathrm{m}^{2}$ ) of broilers fed different dietary energy levels and housed at different stocking densities.

\begin{tabular}{|c|c|c|c|c|c|}
\hline Stocking density ${ }^{1}$ & $\mathrm{FI}$ & WG & FCR & $\mathrm{L}^{3}$ & WA \\
\hline 10 & 4262 & 2311 & 1.84 & $87.1 \mathrm{a}$ & $22.3 c$ \\
\hline 14 & 4232 & 2301 & 1.83 & $82.3 b$ & $33.1 \mathrm{~b}$ \\
\hline 18 & 4222 & 2339 & 1.81 & $78.3 \mathrm{~b}$ & 40.9 a \\
\hline \multicolumn{6}{|c|}{ Dietary energy level² } \\
\hline 2900 & $4303 a$ & 2196 b & $1.95 b$ & 83.3 & $31.2 b$ \\
\hline 3200 & $4174 \mathrm{~b}$ & $2371 \mathrm{a}$ & $1.77 \mathrm{a}$ & 81.8 & $32.9 a$ \\
\hline CV $(\%)$ & 3.55 & 4.21 & 3.41 & 4.49 & 3.68 \\
\hline \multicolumn{6}{|l|}{${ }^{1}$ Birds $/ \mathrm{m}^{2}$} \\
\hline \multicolumn{6}{|l|}{2 kcal ME $/ \mathrm{kg}$} \\
\hline \multicolumn{6}{|c|}{${ }^{3}$ Data transformed in arcsine $x^{1 / 2}$} \\
\hline \multicolumn{6}{|c|}{$\begin{array}{l}\text { a-c - Means followed by the same letter in the same column are not different by the } \\
\text { test of Tukey ( } 5 \%) \text {. }\end{array}$} \\
\hline
\end{tabular}


Dietary energy levels determined significant differences ( $p \leq 0.05$ ) in weight gain, feed intake and feed conversion ratio, but did not affect livability. Feed intake was reduced in 3\%, whereas weight gain and feed conversion ratio improved in 8 and $10 \%$, respectively, as dietary energy level increased from 2,900 to $3,200 \mathrm{kcal} \mathrm{ME} / \mathrm{kg}$ (Table 1). The findings of the present study are consistent with those reported by other authors, who showed that broiler performance improved with increasing dietary energy levels (Bertechini et al., 1991; Zanusso et al., 1999; Sakomura et al., 2004). Some authors associate the better performance observed when energy-rich diets are fed to management conditions and to genetic potential.

On the other hand, seasonal climatic conditions should be taken into consideration when using diets with different energy levels, as it is known that maintenance requirements change when broilers are submitted to conditions outside their thermal comfort zone, particularly at lower temperatures, when their requirements increase. In the present study, tropical winter climate conditions (Figures 1 and 2) were recorded, with hot temperatures during the day and cold nights, which characterizes the so-called "Indian summer". Therefore, environmental temperature variation range is relevant for broilers, which, in addition to the energy for the maintenance of homeothermia, also increase carcass energy reserves (increased fat deposition).

As expected, there was an increase in live weight production per area $\left(\mathrm{kg} / \mathrm{m}^{2}\right)$ as a function of stocking density, which was also described by several other authors (Goldfus et al., 1997; Moreira et al., 2004; Tong et al., 2012). Relative to dietary energy level, production per area significantly increased with dietary energy level (Table 1); however, this effect was only observed in broilers reared at densities of 14 and 18 birds $/ \mathrm{m}^{2}$ (data not shown).

Carcass and parts yield was not influenced ( $p>0.05$ ) neither by stocking density nor by dietary energy level (data not shown). This shows that the dietary energy levels were sufficient supply broilers' requirements for thermoregulation and growth, and did not result in any carcass or parts yield loss. Using different stocking densities and nutritional managements, other authors did not report any effect of stocking density (Tong et al., 2012) or dietary energy level Goldfus, 1997; Campos, 1999; Moreira et al., 2004) on carcass yield. It must be noted that, despite the supply of different dietary energy levels, no significant differences ( $p>0.05$ ) were detected in abdominal fat carcass content (expressed as percentage of live weight) among broilers reared at different stocking densities (data not shown). However, Moreira et al. (2004) reported differences in abdominal fat content in female broilers, but not in males, as it is the case of the present study.

There was no effect of stocking density on sensible heat loss (SRL) or rectal temperature (Table 2). However, the broilers fed the high energy level $(3,200 \mathrm{kcal} M E /$ $\mathrm{kg}$ ), despite not presenting different body temperature compared with those fed 2,900 kcal ME/kg, presented higher sensible heat loss (5.42 and $4.95 \mathrm{~W} /$ bird for the high and the low energy level, respectively). These results suggest that broilers fed high energy levels present unfavorable energy balance compared with those fed low energy levels, particularly under the conditions of the present study (winter), when sensible heat loss becomes relevant for the maintenance of homeothermia.

Table 2 - Effect of dietary energy level, stocking density, and time of the day on broiler sensible heat loss (SRL, Watts) and rectal temperature $\left({ }^{\circ} \mathrm{C}\right)$.

\begin{tabular}{lcc}
\hline Stocking density & $\begin{array}{c}\text { Sensible heat } \\
\text { loss }\end{array}$ & $\begin{array}{c}\text { Rectal } \\
\text { temperature }\end{array}$ \\
\hline $10 \mathrm{birds} / \mathrm{m}^{2}$ & 5.42 & 41.46 \\
$14 \mathrm{birds} / \mathrm{m}^{2}$ & 5.09 & 41.51 \\
$18 \mathrm{birds} / \mathrm{m}^{2}$ & 5.22 & 41.44 \\
\hline Dietary energy level & & \\
\hline $2900 \mathrm{kcal} \mathrm{ME} / \mathrm{kg}$ & $4.95 \mathrm{~b}$ & $41.47 \mathrm{a}$ \\
\hline $3200 \mathrm{kcal} \mathrm{ME} / \mathrm{kg}$ & $5.42 \mathrm{a}$ & $41.47 \mathrm{a}$ \\
\hline Period & & \\
\hline Morning & $7.42 \mathrm{a}$ & $41.23 \mathrm{~b}$ \\
Afternoon & $2.95 \mathrm{~b}$ & $41.71 \mathrm{a}$ \\
\hline $\mathrm{CV}(\%)$ & 4.91 & 0.44 \\
\hline
\end{tabular}

$a, b-$ Means followed by the same letter in the same column are not different by the test of Tukey (5\%).

Considering the thermal variation of the environment, as expected, the results showed important sensible heat loss before dawn (06:30h) compared with zenith (12:30h), with 7.42 vs. $2.95 \mathrm{~W} / \mathrm{bird}$, respectively. Rectal temperatures were also different ( $p \leq 0.05)$, being higher in the afternoon than in the morning (41.71 vs. $41.23^{\circ} \mathrm{C}$ ). These findings show that the lower sensible heat loss in the afternoon resulted in an increase in rectal temperature. These results also demonstrate the importance of environmental management at both times of the day for the maintenance of broiler energy balance, because the difference between skin and environmental temperatures was more important in the morning than in the afternoon. Consequently, 
the heat flow between the bird and the environment is higher in the morning than in the afternoon. Havenstein et al. $(2003 a, b)$ showed that the cardiovascular and respiratory systems of fast-growing broilers are not well developed, and these systems are critical for the control of latent or sensible heat exchange mechanisms. Therefore, in addition to the genetic traits associated to fast growth, it is difficult to broilers to dissipate heat, thereby increasing their sensitivity to environmental stresses. Sensible heat loss capacity may be increased by early thermal conditioning, with lower radiation and convection losses, as shown by Yahav et al. (2005). However, in the present study, birds were no submitted to this early conditioning, and therefore, the higher or lower sensible heat loss observed is associated to temperature differences between the skin and the environment.

\section{CONCLUSIONS}

Based on the present results, it is concluded that sensible heat loss depends on dietary energy levels and particularly on time of the day, with significant losses before dawn. Therefore, proper environmental house management is suggested in order to reduce temperature differences between broiler skin and the environment in the morning and in the afternoon.

\section{REFERENCES}

Bertechini AG, Rostagno HS, Soares PR, Oliveira AIG. Efeitos de programas de alimentação e níveis de energia da ração sobre o desempenho e a carcaça de frangos de corte. Revista Brasileira de Zootecnia 1991;20:267-280.

Campos S S. Efeitos da energia dietética, densidade populacional, altura de cama e época do ano sobre parâmetros termorreguladores, zootécnicos e da cama em frangos de corte [tese]. Jaboticabal (SP): Universidade Estadual Paulista; 1999.

Dozier WA, Thaxton JP, Branton SL, Morgan GW, Miles DM, Roush WB, Lott $B D$, Vizzier-Thaxton Y. Stocking density effects on growth performance and processing yields of heavy broilers. Poultry Science 2005;84:13321338.

Dozier, WA, Thaxton J P,Purswelln JL, Olanrewaju HA, Branton SL, Roush WB. Stocking density effects on male broilers grown to 1.8 kilograms of body weight. Poultry Science 2006; 85:344-351.

DuarteKF, Junqueira OM, Filardi RS, Laurentiz AC, Souza HBA, Oliveira TMFS. Efeito dos níveis de energia e programas de alimentação sobre a qualidade de carcaça e desempenho de frangos de corte abatidos tardiamente. ActaScientiarum 2007;29:39-47.

Estevez I. Density allowances for broilers: Where to set the limits? Poultry Science 2007;86:1265-1272.

FeddesJJR,Emmanuel EJ, Zuidhof MJ. Broiler performance, bodyweight variance, feed and water intake, and carcass quality at different stocking densities. Poultry Science 2002;81:774-779.
GoldfusF,Ariki J, Kronka SN, Sakomura NK, Moraes, VMB.Efeitos da densidade populacional e da energia da dieta sobre o desempenho de frangos de corte. Revista Brasileira de Zootecnia 1997;26:310-315.

HavensteinGB, Ferket PR, Qureshi MA. Growth, livability, and feed conversion of 1957 versus 2001 broilers when fed representative 1957 and 2001 broiler diets.Poultry Science2003a; 82:1500-1508.

HavensteinGB, Ferket PR, QureshiMA.Carcass composition and yield of 1957versus 2001 broilers when fed representative 1957 and 2001 broiler diets. Poultry Science 2003b;82:1509-1518.

MoreiraJ, Mendes AA, Roça RO,Garcia EA, Naas IA, Garcia RG, Paz ICLA Efeito da densidade populacional sobre o desempenho e rendimento de carcaça e qualidade de carne em frangos de corte de diferentes linhagens comerciais. Revista Brasileira de Zootecnia 2004;33:15061519 .

Oliveira Neto AR, Oliveira, RFM, Donzele JL, Rostagno HS, Ferreira RA, Carmo HM. Níveis de energia metabolizável para frangos de corte no período de 22 a 42 dias de idade mantidos em ambiente termoneutro. Revista Brasileira de Zootecnia 2000;29:1132-1140.

PuronD,Santamaria R, Segura JC,Alamilla JL. Broiler performance at different stocking densities. Journal Applied Poultry Research 1995;4: 55-60.

Rostagno HS,Albino LFT, Donzele JL, Gomes PC, Oliveira RF, Lopes DC, Ferreira AS,Barreto SLT. Tabelas brasileiras para aves e suínos. Composição de alimentos e exigências nutricionais. 2 ed. Viçosa (MG): Departamento de Zootecnia; 2005.

SAS Institute. User'sguidestatistics.Cary; 2000.

SakomuraNK, Longo FA, RabelloCBV, Watanabe K,PelíciaK,Freitas ER. Efeito do nível de energia metabolizável da dieta no desempenho e metabolismo energético de frangos de corte. RevistaBrasileira de Zootecnia 2004;33:1758-1767

Simsek UG,Cerci I H, Dalkilic B, Yilmaz O, Ciftc, M. Impact of stocking density and feeding regimen on broilers: Chicken meat composition, fatty acids, and serum cholesterol levels. Journal Applied Poultry Research 2009; 18:514-520.

Sorensen P, SuG, KestinSC. Effects of age and stocking density on leg weakness in broiler chickens. Poultry Science 2000;79:864-870.

Tong HB, Lu J, Zou JM, Wang Q, Shi SR. Effects of stocking density on growth performance, carcass yield, and immune status of a local chicken breed. Poultry Science 2012;91:667-673.

YahavS, ShinderD, TannyJ, CohenS. Sensible heat loss: the broiler's paradox. World's Poultry Science Journal 2005;61:419-434.

ZanollaN, Tinôco IFF,Baêta FC, CeconPR,Moraes SRP. Sistemas de ventilação em túnel e lateral na criação de frangos de corte em alta densidade. Revista Brasileira de Engenharia Agrícola e Ambiental 1999;3:361-366.

Zanusso JT, Oliveira RFM, Donzele JL, Ferreira RA, Rostagno HS, Euclydes RF, ValerioSR. Níveis de energia metabolizável para frangos de corte de 1 a 21 dias de idade mantidos em conforto térmico. Revista Brasileira de Zootecnia 1999;28:1068-1074 